\title{
Localization of a FMRFamide-related peptide in efferent neurons and analysis of neuromuscular effects of DRNFLRFamide $\left(\mathrm{DF}_{2}\right)$ in the crustacean Idotea emarginata.
}

\author{
Torsten Weiss, $\nmid$ Sabine Kreissl and Werner Rathmayer \\ Department of Biology, University of Konstanz, D 78457 Konstanz, Germany
}

Keywords: immunohistochemistry, modulation, muscle contraction, neuropeptide

\begin{abstract}
In the ventral nerve cord of the isopod Idotea emarginata, FMRFamide-immunoreactive efferent neurons are confined to pereion ganglion 5 where a single pair of these neurons was identified. Each neuron projects an axon into the ipsilateral ventral and dorsal lateral nerves, which run through the entire animal. The immunoreactive axons form numerous varicosities on the ventral flexor and dorsal extensor muscle fibres, and in the pericardial organs. To analyse the neuromuscular effects of a FMRFamide, we used the DRNFLRFamide $\left(\mathrm{DF}_{2}\right) . \mathrm{DF}_{2}$ acted both pre- and postsynaptically. On the presynaptic side, $\mathrm{DF}_{2}$ increased transmitter release from neuromuscular endings. Postsynaptically, $\mathrm{DF}_{2}$ depolarized muscle fibres by approximately $10 \mathrm{mV}$. This effect was not observed in leg muscles of a crab. The depolarization required $\mathrm{Ca}^{2+}$, was blocked by substituting $\mathrm{Ca}^{2+}$ with $\mathrm{Co}^{2+}$, but not affected by nifedipine or amiloride. In Idotea, $\mathrm{DF}_{2}$ also potentiated evoked extensor muscle contractions. The amplitude of high $\mathrm{K}^{+}$contractures was increased in a dose dependent manner with an $\mathrm{EC}_{50}$ value of $40 \mathrm{nM}$. In current-clamped fibres, $\mathrm{DF}_{2}$ strongly potentiated contractions evoked by current pulses exceeding excitation-contraction threshold. In voltage-clamped fibres, the inward current through L-type $\mathrm{Ca}^{2+}$ channels was increased by the peptide. The observed physiological effects together with the localization of FMRFamide-immunoreactive efferent neurons suggest a role for this type of peptidergic modulation for the neuromuscular performance in Idotea. The pre- and postsynaptic effects of $\mathrm{DF}_{2}$ act synergistically and, in vivo, all should increase the efficacy of motor input to muscles resulting in potentiation of contractions.
\end{abstract}

\section{Introduction}

Since the isolation of the tetrapeptide FMRFamide from the clam Macrocallista nimbosa (Price \& Greenberg, 1977), more than 100 different FMRFamide-related peptides (FaRPs) have been characterized. This high number makes members of this peptide family one of the most abundant modulators. They are present in the nervous system of all major invertebrate groups, particularly of arthropods (for summary, see Greenberg \& Price, 1992; Orchard et al., 2001; Sithigorngul et al., 2002), and have been found in all classes of vertebrates (for references see Oelschläger et al., 1998; Askwith et al., 2000). FaRPs are involved in heterogeneous modulation in multiple targets. In arthropods, they exert excitatory and inhibitory effects on heartbeat, and on contractions of visceral and skeletal muscles (for summary in insects, see Orchard et al., 2001; in crustaceans, Tierney et al., 1997). In addition to the peripheral effects on neuromuscular parameters, FaRPs also modulate activity in neuronal networks such as the crustacean stomatogastric central pattern generators (Weimann et al., 1993; Tierney et al., 1997; Jorge-Rivera et al., 1998).

Correspondence: Professor Dr Werner Rathmayer, as above.

E-mail: werner.rathmayer@uni-konstanz.de

$\dagger$ Present address: Institute of Anatomy, University Hospital Charité, Humboldt-University Berlin, 10115 Berlin, Germany
In crustaceans, 19 distinct FaRPs have been identified so far (Marder et al., 1987; Trimmer et al., 1987; Krajniak, 1991; Mercier et al., 1993; Weimann et al., 1993; Sithigorngul et al., 1998, 2001, 2002). They all share a common C-terminal sequence, the tetrapeptide XLRFamide (with $\mathrm{X}$ standing for $\mathrm{F}$ or $\mathrm{R}$ ). The isolation and identification of crustacean FaRPs have progressed much faster than the investigation of their physiological roles. Four of the peptides have been shown to increase transmitter release from neuromuscular endings in crab, crayfish and lobster (Kravitz et al., 1980; Mercier et al., 1990, 1993; Krajniak, 1991; Pasztor \& Golas, 1993; Skerrett et al., 1995; Worden et al., 1995; Jorge-Rivera \& Marder, 1996; Friedrich et al., 1998; Rathmayer et al., 2002a). For one of these, DRNFLRFamide $\left(\mathrm{DF}_{2}\right)$, it was recently demonstrated that the increase of transmitter release at crab neuromuscular terminals is mediated by selective axontype-specific modulation of presynaptic $\omega$-conotoxin-sensitive $\mathrm{N}$-type $\mathrm{Ca}^{2+}$ channels (Rathmayer et al., 2002a). In contrast to the wellstudied presynaptic effects, little is known about the postsynaptic mechanisms underlying the potentiation of muscle contraction by FaRPs. This investigation was the aim of the present study. In muscle fibres of the isopod crustacean Idotea, the peptide induces depolarization accompanied by a decrease in input resistance. In addition, $\mathrm{DF}_{2}$ increases the inward $\mathrm{Ca}^{2+}$ current that provides the $\mathrm{Ca}^{2+}$ required to activate contraction. These postsynaptic effects, together with a $\mathrm{DF}_{2}$ induced presynaptic increase of transmitter release, imply a role of a FMRFamide-related peptide in muscle performance in Idotea. One in 
vivo-source for the peptide is a single pair of FMRFamide-immunoreactive neurons in the ventral nerve cord.

\section{Materials and methods}

\section{Animals}

Adult males of the marine isopod Idotea emarginata were used for all experiments. Specimens of $1020 \mathrm{~mm}$ body length were obtained from the Marine Station at Helgoland (Germany) and reared at the Animals Facility of the University of Konstanz. Animals were kept in tanks with circulating artificial seawater (ASW, see below) under a 14-h light : 10h dark cycle at $16^{\circ} \mathrm{C}$.

\section{Immunohistochemistry}

Immunohistochemical staining with a FMRFamide antiserum was performed on wholemount preparations of isolated ventral nerve cord and dorsal extensor muscles. Tissue dissection procedure was as follows. After anaesthetizing the animal by chilling, the head and the legs were removed. Specimens were pinned ventral side up in a Sylgard-coated dish. The pereion sternites with attached flexor muscles and the ventral nerve cord were removed. The nerve cord comprising all pereion and pleon ganglia was isolated by cutting the segmental nerves. From the dorsal body half, the gut, gonads, and heart were removed to expose the extensor muscle fibres with peripheral nerve branches attached. The staining procedure used for immunohistochemical identification of FMRFamide-immunoreactive (FMRFa-ir) neurons, axons and their neuromuscular terminals followed that described previously (Kreissl et al., 1999). Briefly, dorsal or ventral body halves and isolated nerve cords were fixed in $4 \%$ paraformaldehyde in $0.1 \mathrm{M}$ phosphate buffer at $\mathrm{pH} 7.4$ for $24 \mathrm{~h}$ at $4{ }^{\circ} \mathrm{C}$. After washing with phosphate buffered saline (PBS) containing $0.5 \%$ Triton X-100 (PBSX 0.5), the preparations were incubated in a $1: 1000$ solution of the primary antiserum $(\alpha$-FMRFamide; DiaSorin, Stillwater, MN, USA) in PBSX 0.5 with $0.2 \%$ bovine serum albumin for $1218 \mathrm{~h}$ at $4{ }^{\circ} \mathrm{C}$. The tissue was rinsed with PBSX 0.1. Binding of the primary antiserum was visualized using a $\mathrm{Cy} 3$-conjugated goat antirabbit IgG (Jackson ImmunoResearch Laboratories, West Grove, PA, USA). The secondary antiserum was applied at a dilution of $1: 600$ in PBSX 0.5 for at least $6 \mathrm{~h}$. After final washes in PBS, preparations were dehydrated, mounted in $90 \%$ glycerol and examined with a Zeiss fluorescence microscope.

\section{Retrograde axonal staining and fluorescence double labelling}

To identify FMRFa-ir neurons innervating the extensor muscle fibres, retrograde filling with Lucifer Yellow (Molecular Probes, Eugene, OR, USA) was combined with immunostaining. Double labelling experiments were performed as described previously (Kreissl et al., 1999). Backfilling nerves N3B, which supply the pereional extensor muscles, with a $3.5 \%$ solution of Lucifer Yellow achieved staining of efferent neurons within the pereion ganglia. Diffusion and retrograde transport of the dye were allowed to take place at room temperature for approximately $1 \mathrm{~h}$. Isolated nerve cords were subsequently fixed in $4 \%$ paraformaldehyde in $0.1 \mathrm{M}$ phosphate buffer at pH 7.4 for $24 \mathrm{~h}$. After washing with PBSX 0.5, preparations were dehydrated and mounted in glycerol. Ganglia were examined under fluorescence before further immunostaining. Successfully filled Lucifer Yellow preparations were processed with the FMRFamide antiserum as described above.

The preparations were examined with a Zeiss Axiovert 35 fluorescence microscope using appropriate filter combinations. Photographs were taken with a conventional camera and subsequently improved by digital processing using Photoshop 6.0 software (Adobe Systems Inc., San Jose, CA, USA) to obtain compound illustrations.

\section{Electrophysiological techniques}

For all experiments in Idotea, the individually identifiable extensor muscle fibre 2 of pereion segment 7 was used (for anatomical details, see Kreissl et al., 1999). To expose the extensor muscle, the preparation was pinned ventral side up in a Sylgard-coated dish. Pereion sternites with attached flexor muscles and the ventral nerve cord were removed. Excitatory postsynaptic currents (EPSCs) were elicited focally by stimulating individual release boutons with depolarizing current pulses of $0.10 .5 \mathrm{~ms}$ duration and $28 \mu \mathrm{A}$ amplitude through a macropatch electrode (Zeitz Instruments, Augsburg, Germany; for details of recording from and stimulating of release boutons in Idotea, see Kreissl et al., 1999). The macropatch electrodes had tip openings of approximately $10 \mu \mathrm{m}$ diameter and a DC resistance of $0.10 .3 \mathrm{M} \Omega$. EPSCs were stored on a PC using a DigiData 1200 interface (Axon Instruments, Foster City, CA, USA) and pClamp acquisition software (Axon Instruments).

For electrophysiological experiments with the crab Eripha spini frons, fibres of the closer muscle from walking legs were used. The preparation has been described in detail previously (Rathmayer \& Erxleben, 1983).

Intracellular recordings and current-/voltage-clamp measurements were performed using an AxoClamp 2B amplifier (Axon Instruments). Pulse protocols and data acquisition were controlled with the help of pClamp 8.0 software (Axon Instruments). Conventional intracellular electrodes were filled with a $1: 1$ mixture of $3 \mathrm{M} \mathrm{KCl}$ and $\mathrm{K}^{+}$citrate and had DC resistances between 1.5 and $5 \mathrm{M} \Omega$. A grounded shield was placed between the two microelectrodes during the clamp experiments to reduce capacitative coupling. Current-clamp measurements were performed by intracellular injection of constant current pulses of 150 $300 \mathrm{~ms}$ duration and increasing amplitude with the resulting voltage responses and associated contractions recorded simultaneously from the same fibres. Details for using the two-electrode voltage clamp in muscle fibres of Idotea and the quantitative analysis of the major membrane currents have been described recently (Weiss et al., 2001). In brief, depolarization-activated membrane inward currents were

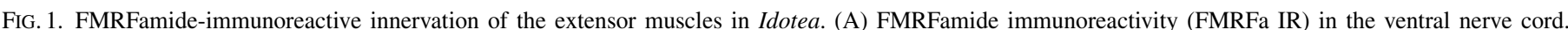

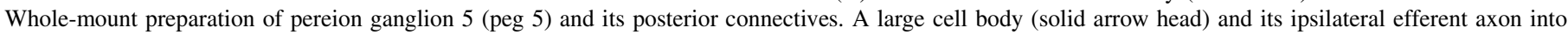

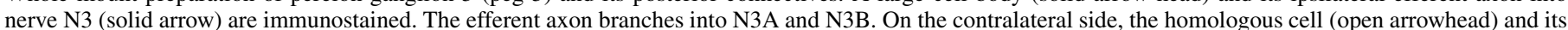

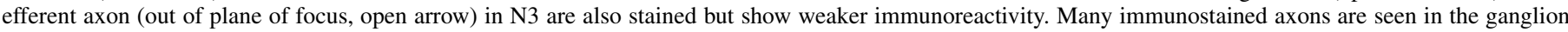

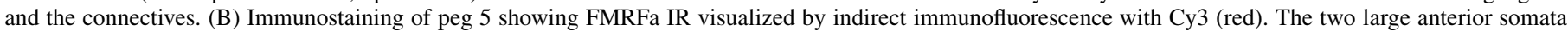

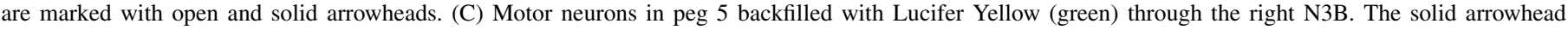

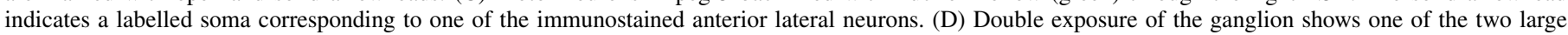

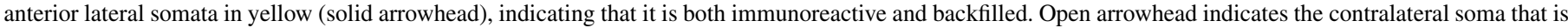

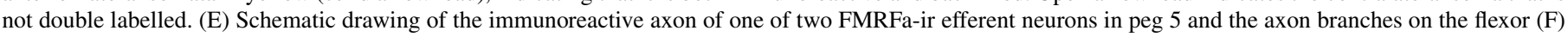

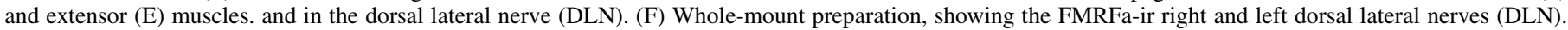

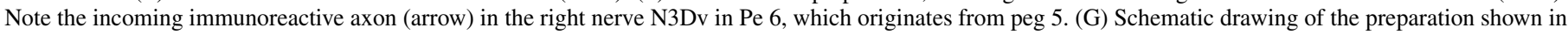

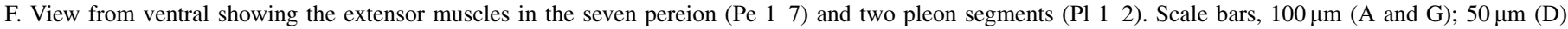
applies also for B and C; $500 \mu \mathrm{m}(\mathrm{F})$. 


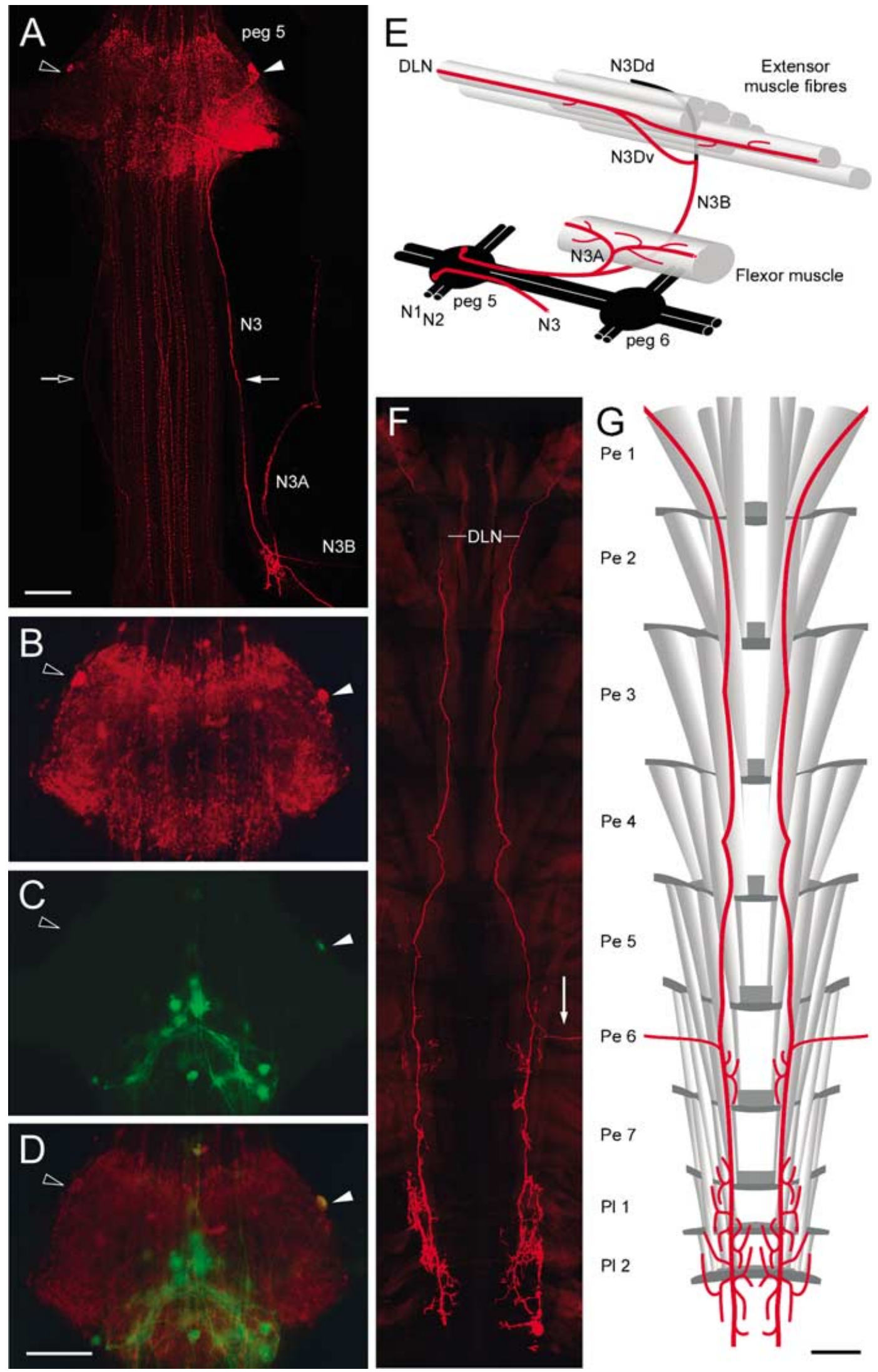


recorded in two-electrode voltage-clamp conditions. Currents were elicited from a holding potential of $-70 \mathrm{mV}$ by short $(100200 \mathrm{~ms})$ depolarizing voltage steps to potentials between -60 and $+20 \mathrm{mV}$. Current records were digitized at $10 \mathrm{kHz}$, leak subtracted with a $\mathrm{P} / 4$ protocol and filtered at $3 \mathrm{kHz}$ during acquisition. Data analysis was performed using pClamp 8.0 (Axon Instruments) and Origin 6.0 (Microcal Software, Inc., Northampton, MA, USA).

\section{Contraction measurements}

In preparations dissected as described above for electrophysiological recordings, the intersegmental membrane between pereion segment 6 and 7 was cut and pleon segment 1 was transected to yield an isolated preparation consisting of the dorsal half of pereion segment 7 only. The remaining parts of the long fibres 5 and 6, which span two segments, were then removed. The cleaned preparation contained only the short fibres 1 4, but in many experiments (e.g. high $\mathrm{K}^{+}$contractures) fibres 3 and 4 were cut to prevent them from contributing to force generation leaving only fibre 2 and the thin fibre 1 intact. The final preparation was transferred into a small bath $(300 \mu \mathrm{L}$ volume $)$ lined with Sylgard. The anterior rim of pereion segment 7 was fixed with fine pins. The posterior end of the preparation was attached to a small metal pin connected to a force transducer for recording muscle tension (see below). Finally, the preparation was stretched to in situ resting length of the muscle fibres. This tension was taken as zero tension in the contraction measurements. The bath was continuously perfused with cooled $\left(18^{\circ} \mathrm{C}\right) \mathrm{ASW}$ at a flow rate of $0.52 .5 \mathrm{~mL} / \mathrm{min}$. Substituted solutions and drugs were applied to the bath with the help of a switching port in the perfusion system.

Brief contractions were evoked by intracellular injection of depolarizing current pulses. Prolonged contractions were induced by elevated extracellular potassium (high $\mathrm{K}^{+}$contractures). Muscle tension was measured isometrically with a KG3 force transducer (Scientific Instruments Güth, Heidelberg, Germany). Tension records were digitized at $10 \mathrm{kHz}$ and low-pass filtered between 0.5 and $3 \mathrm{kHz}$ with an eight-pole Bessel filter.

All numerical data are expressed as mean \pm SEM. Statistical evaluation was performed applying a Student's $t$-test for paired data (Origin 6.0). $P$-values of less than 0.05 were considered to indicate a significant difference between means.

\section{Physiological solutions and chemicals}

Artificial seawater (ASW) used as saline contained (in mM) $490 \mathrm{NaCl}$, $8 \mathrm{KCl}, 10 \mathrm{CaCl}_{2}, 48 \mathrm{MgCl}_{2}, 30 \mathrm{D}(+)$-glucose and 20 HEPES buffer at pH 7.4. $\mathrm{Co}^{2+}$ - and $\mathrm{Ba}^{2+}$-ASW were prepared by replacing $\mathrm{CaCl}_{2}$ with $\mathrm{CoCl}_{2}$ or $\mathrm{BaCl}_{2}$, respectively. In experiments where high $\mathrm{K}^{+}$ (20 $100 \mathrm{mM}$ ) was used to induce muscle contractures, $\mathrm{Na}^{+}$was substituted with equimolar $\mathrm{K}^{+}$. Tetraethylammonium (TEA)/4-aminopyridine (4-AP)-ASW was made by substituting TEA ( $490 \mathrm{mM}$ ) for $\mathrm{Na}^{+}$and adding 4-AP (10 mM) to the solution without substitution. $\mathrm{BaCl}_{2}, \mathrm{CoCl}_{2}$, TEA and 4-AP were obtained from Sigma (Deisenhofen, Germany). Other chemicals were purchased from Roth (Karlsruhe, Germany).

Amiloride (Sigma), used at a concentration of $10 \mu \mathrm{M}$, was diluted in ASW from a stock solution of $10 \mathrm{mM}$ dissolved in distilled water. Nifedipine (Biotrend, Köln, Germany) was made up in dimethyl sulfoxide before being dissolved in ASW to the desired concentration $(50 \mu \mathrm{M})$, resulting in a DMSO concentration of $0.2 \%$ in the physiological solutions used in respective experiments. Control measurements revealed no observable effects of $0.2 \%$ DMSO alone on properties or responses of extensor muscle fibres (Weiss et al., 2001). Synthetic $\mathrm{DF}_{2}$ with the amino acid sequence DRNFLRF-NH $\mathrm{N}_{2}$ was purchased from Sigma. The peptide was dissolved in distilled water at a concentration of $1 \mathrm{mM}$, lyophilized and stored at $-30{ }^{\circ} \mathrm{C}$. Stock solutions were
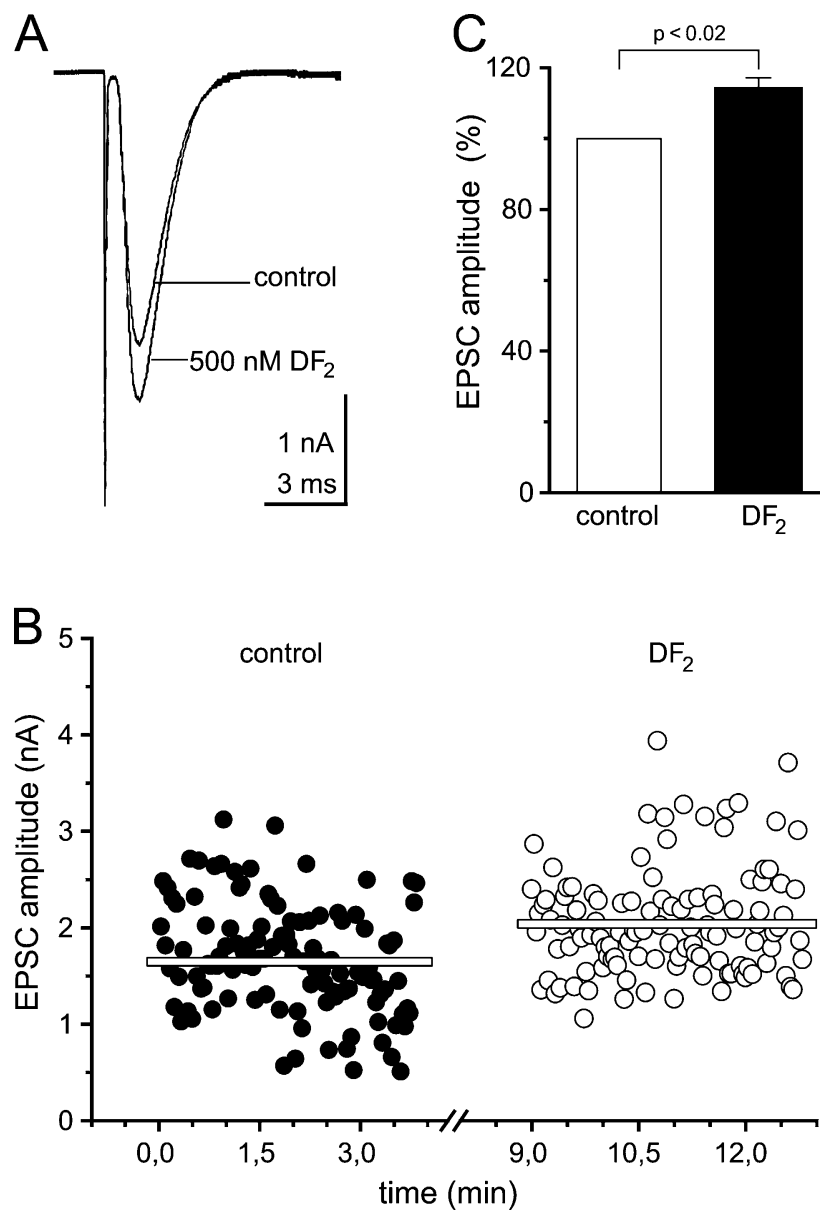

FIG. 2. $\mathrm{DF}_{2}$ increases the amplitude of EPSCs at neuromuscular junctions in Idotea. (A) Sample record of EPSCs elicited by direct stimulation of transmitter release from an individual release bouton by a macropatch electrode. 150 samples were averaged for the control and in the presence of $500 \mathrm{nM} \mathrm{DF}_{2}$. (B) Typical experiment. After establishing the controls by recording EPSCs every $2 \mathrm{~s}$ over $4 \mathrm{~min}, \mathrm{DF}_{2}$ was added (final concentration $500 \mathrm{nM}$ ). After $5 \mathrm{~min}$, recording of EPSCs was resumed for $4 \mathrm{~min}$. The mean EPSC amplitude was increased from 1.7 to $2.1 \mathrm{nA}$. (C) Summary of 7 experiments with the mean EPSC amplitudes in controls normalized.

aliquoted and diluted in ASW to the desired concentrations just prior to the experiments.

\section{Results}

\section{FMRFamide-immunoreactivity in efferent neurons}

Staining the ventral nervous system of Idotea with an antiserum against the tetrapeptide FMRFamide revealed in each of 22 preparations extensively ramifying axon processes in all seven pereion ganglia. A number of immunoreactive axons run through the connectives and traverse in a dorsal tract the entire ventral nerve cord. Some of the axons belong to FMRFamide-immunoreactive (FMRFa-ir) interneurons of small soma size, which are present in all ganglia. In addition to the small interneurons, a single pair of large FMRFa-ir neurons (soma diameter 30 $35 \mu \mathrm{m}$ ) was consistently located anterolaterally in pereion ganglion 5 (peg 5, Fig. 1A and B, arrowheads). The axons of these two neurons exit peg 5 ipsilaterally through nerves N3 (Fig. 1A, filled arrow). To verify that this pair of FMRFa-ir neurons is involved in the innervation of muscles, a double-staining procedure was employed using Lucifer Yellow backfills (green) and FMRFamide immunohistochemistry (red). Of the 18 efferent neurons stained by unilateral backfilling of 
nerve $\mathrm{N} 3 \mathrm{~B}$ of peg 5 only one is located in the ipsilateral-anterolateral part of the ganglion (Fig. 1C, arrowhead). This neuron is therefore unambiguously identifiable in all preparations. After treatment of five successfully backfilled preparations with the FMRFamide-antiserum, double exposure showed that this cell body appeared yellow, indicating that it contained both fluorescent markers (Fig. 1D, solid arrowhead). The contralateral cell body lacking Lucifer Yellow stained only with the FMRFamide-antiserum (Fig. 1D, open arrowhead). The two anterolateral cells in peg 5 are the only efferent neurons within the entire ventral nerve cord that are FMRFamide-immunoreactive. The axon of each FMRFa-ir neuron exits through N3 of pereion segment 5 (Pe 5) and, at the branching point of $\mathrm{N} 3$ in the next posterior segment $(\mathrm{Pe} 6)$, bifurcates and enters the two nerve branches N3A and N3B (Fig. 1A and $\mathrm{E}$ ). The axon branch in $\mathrm{N} 3 \mathrm{~A}$ joins the ventral sinus nerve (Demassieux, 1979) and forms numerous varicose arborizations on most flexor muscle fibres in the entire pereion and the anterior two pleon segments. The abundance of FMRFa-ir varicosities is highest on flexor muscle fibres in segments Pe 7 to Pl 2 and decreases anteriorwards. In Pe 1, only the median muscle fibres receive FMRFa-ir innervation. The FMRFa-ir axon branch in N3B of peg 5 also extends into N3Dv in Pe 6, which approaches the deep, i.e. ventral layer of the two-segmental fibres of the extensor muscle. It projects into the dorsal lateral nerve (DLN) and divides into an anterior and a posterior branch (Fig. 1E and G). The anterior branch of the FMRFa-ir axon remains within the DLN and extends anteriorwards to the head without forming arborizations on the extensor muscle fibres in segments Pe 1 to Pe 5 (Fig. 1G). In these segments, the DLN runs longitudinally on the anterior parts of the two segmental muscle fibres 5 (for details of anatomy see Kreissl et al., 1999). The posterior branch gives rise to numerous FMRFa-ir arborizations in segments Pe 6 to Pl 2, which contribute to the dense meshwork of varicose axon endings within the pericardial organ (Fig. 1G).

\section{Effects of $\mathrm{DF}_{2}$ on transmitter release}

The localization of FMRFa-ir efferent neurons with axons projecting to flexor and extensor muscles suggests a role for one or several members of this peptide family in the modulation of neuromuscular parameters. We have selected one member of this peptide family, the DRNFLRFamide $\mathrm{DF}_{2}$ because it has been shown previously to occur in the nervous system of crustaceans (Trimmer et al., 1987) and has been used in a number of studies in other crustacean preparations. $\mathrm{DF}_{2}$ has

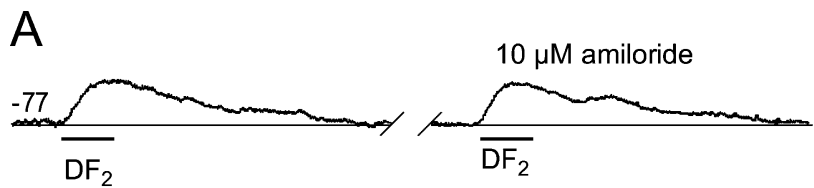

B
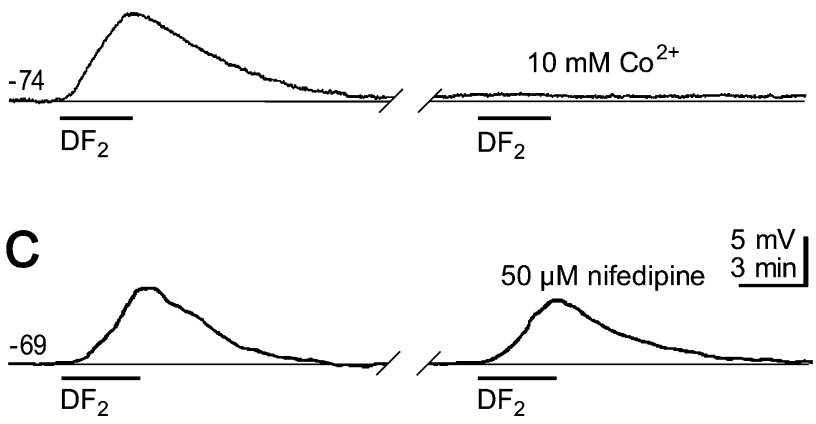

FIG. 3. $\mathrm{DF}_{2}$-induced membrane depolarization of extensor muscle fibres in Idotea depends on extracellular $\mathrm{Ca}^{2+}$. (A C) Samples of membrane potential recordings (resting value given in the left recordings in $\mathrm{mV}$ and represented by the thin lines) from three different fibres in control ASW (left traces) and after 15 min superfusion with ASW (right traces) containing $10 \mu \mathrm{M}$ amiloride (A), $10 \mathrm{mM} \mathrm{Co}^{2+}(\mathrm{B})$ and $50 \mu \mathrm{M}$ nifedipine $(\mathrm{C})$. The bars indicate the application of $100 \mathrm{nM} \mathrm{DF}_{2}$. Time and voltage scalings given in $\mathrm{C}$ also apply to $\mathrm{A}$ and $\mathrm{B}$.

been shown to increase the number of transmitter quanta released at neuromuscular endings in crayfish and crab (Mercier et al., 1990, 2002; Skerret et al., 1995; Rathmayer et al., 2002a). In Idotea, application of $\mathrm{DF}_{2}(500 \mathrm{nM})$ also increased the amplitude of excitatory postsynaptic currents (EPSCs) evoked by direct stimulation of individual release boutons on extensor muscle fibres through a macropatch electrode (Fig. 2A). Figure 2B illustrates a typical experiment. The mean amplitude of the EPSCs in the controls $(1.7 \mathrm{nA})$ was increased in the presence of the peptide to $2.1 \mathrm{nA}$. The average increase of the EPSC amplitudes was $14 \pm 4 \%$ and statistically significant $(P \leq 0.02$, $n=7$, Fig. 2C).

\section{Effects of $\mathrm{DF}_{2}$ on membrane potential and input resistance}

The average membrane potential of the fibres studied in this investigation was $-72 \pm 1 \mathrm{mV}$. In all experiments, application of $100 \mathrm{nM} \mathrm{DF}_{2}$
A

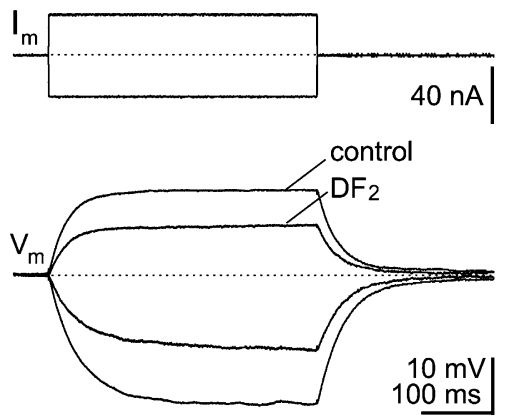

B

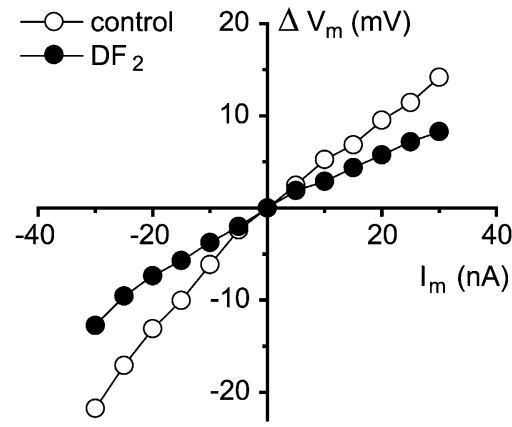

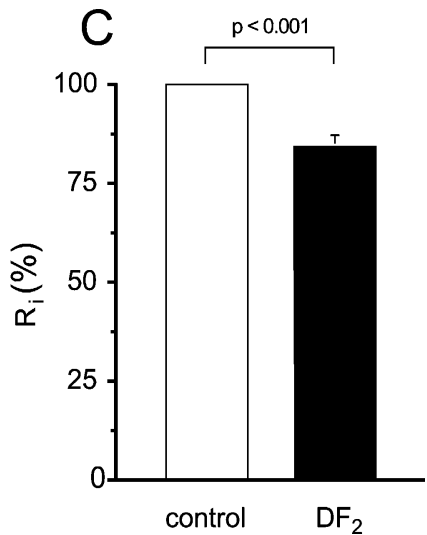

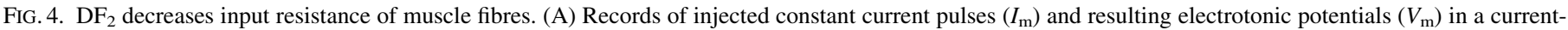

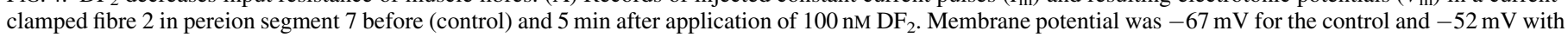

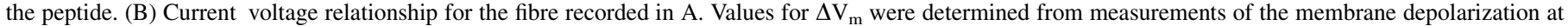
the end of the current pulses. (C) Summary of 18 experiments showing input resistance $\left(\mathrm{R}_{\mathrm{i}}\right)$ normalized in controls and in the presence of $100 \mathrm{nM} \mathrm{DF}_{2}$. 

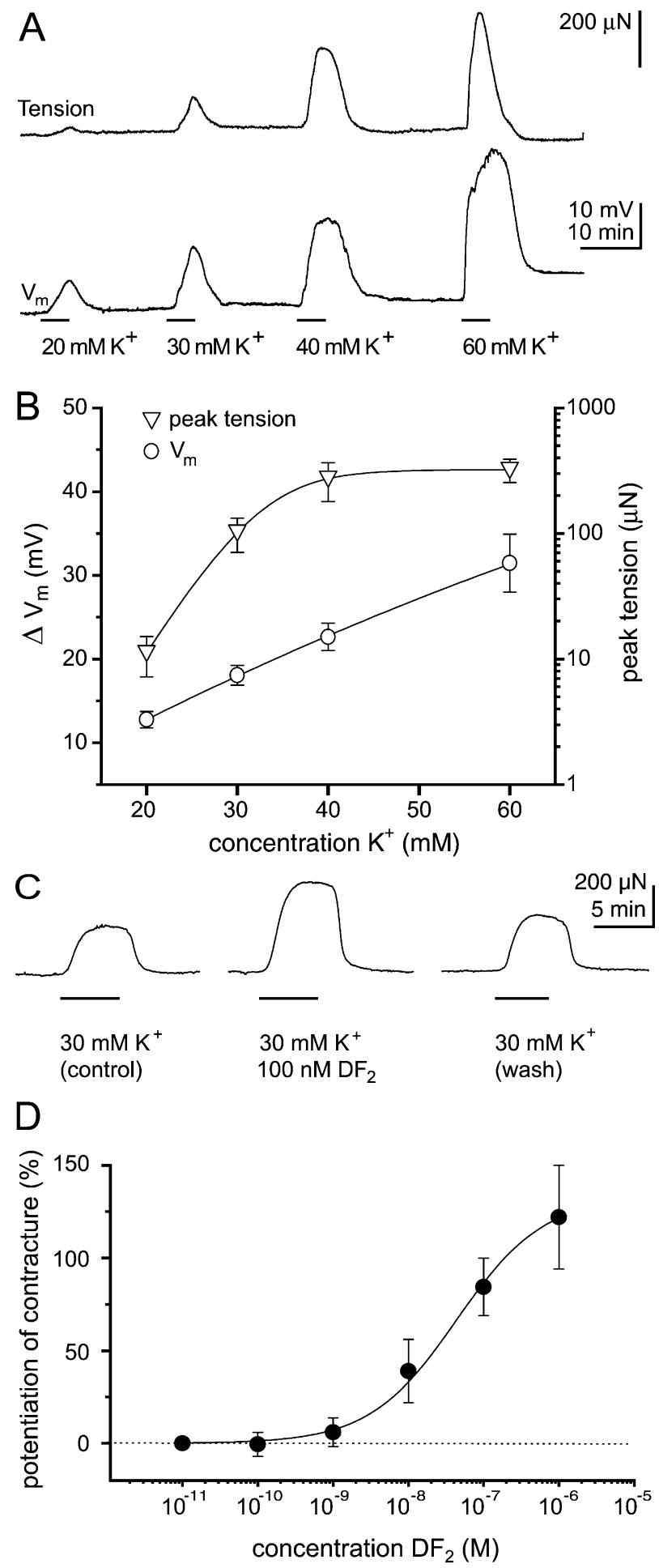

FIG. 5. $\mathrm{DF}_{2}$ enhances the amplitude of $\mathrm{K}^{+}$contractures of extensor muscle fibre in Idotea. (A) Tension and membrane potential measured simultaneously at increasing extracellular $\mathrm{K}^{+}$concentrations in the range of $2060 \mathrm{mM}$. (B) Relationship between tension generation and membrane depolarization in $\mathrm{K}^{+}$ contractures illustrated as plot of membrane potential $\left(V_{\mathrm{m}}\right)$ and contracture peak amplitude (peak tension) as a function of the extracellular $\mathrm{K}^{+}$concentration. (C) Representative tension records of a preparation measured with $30 \mathrm{mM} \mathrm{K}^{+}$-ASW under control conditions, in the presence of $100 \mathrm{nM} \mathrm{DF}_{2}$ and after washing. Breaks between the traces indicate superfusion of the preparation with normal $\mathrm{ASW}$ for $15 \mathrm{~min}$. (D) Dose response curve of the $\mathrm{DF}_{2}$ effect on peak amplitude of $\mathrm{K}^{+}$contractures. Increase in contracture amplitude (normalized) is plotted as a function of peptide concentration. Bars in B and D represent mean \pm SEM. significantly depolarized the fibres to an average value of $-64 \pm 1 \mathrm{mV}$ $(P \leq 0.01, n=52)$. Although the peptide-induced depolarization of the muscle fibres led to a small decrease in the amplitude of individual excitatory postsynaptic potentials due to a decrease in electrical driving force, the overall amplitude of membrane depolarizations achieved by junction potentials riding on top of the peptide-induced depolarization was always higher in the presence of the peptide (data not shown). The change in membrane potential by approximately $10 \mathrm{mV}$ was almost completely reversed after washing in normal ASW. As illustrated in Fig. 3A, the $\mathrm{DF}_{2}$-induced depolarization was not affected by amiloride $(10 \mu \mathrm{M}, n=4)$, which has been shown to block FMRFamide-induced depolarization in molluscan neurons (Ruben et al., 1986). In contrast, substitution of $\mathrm{Ca}^{2+}$ by $\mathrm{Co}^{2+}$, which is an effective $\mathrm{Ca}^{2+}$ channel blocker in these muscles (Weiss et al., 2001), abolished the peptide response completely (Fig. 3B). Total inhibition of the $\mathrm{DF}_{2}$ effect on membrane resting potential was observed in six preparations altogether, suggesting at least participation of $\mathrm{Ca}^{2+}$ in this depolarization. However, application of $50 \mu \mathrm{M}$ nifedipine, an effective blocker of high-voltage-activated L-type $\mathrm{Ca}^{2+}$ channels in these fibres (Erxleben \& Rathmayer, 1997), was without effect (Fig. 3C, $n=4$ ) indicating that this type of $\mathrm{Ca}^{2+}$ channel is not involved in the effect.

As the depolarization of muscles by $\mathrm{DF}_{2}$ observed consistently in Idotea is in contrast to reports in other crustacean muscle preparations (for references see Discussion), we have looked into a different nervemuscle preparation, the closer muscle of the crab Eriphia spinifrons. In this preparation, $\mathrm{DF}_{2}$ had no effect on membrane potential $(n=5$, data not shown).

To quantify the peptide-evoked increase in membrane conductance observed in muscles of Idotea, input resistance $\left(\mathrm{R}_{\mathrm{i}}\right)$ was determined under two-electrode current-clamp conditions in control ASW and in the presence of the peptide. $\mathrm{R}_{\mathrm{i}}$ varied considerably in the controls and ranged from 73 to $764 \mathrm{k} \Omega$ with an average at $311 \pm 38 \mathrm{k} \Omega(n=18)$ which is lower than that found in a previous study and probably due to seasonal effects (Weiss et al., 2001). Figure 4A illustrates a typical peptide effect observed in a current-clamped fibre. Application of $100 \mathrm{nM} \mathrm{DF}_{2}$ reduced the amplitude of electrotonic potentials. $R_{i}$, determined from the slope of the linear part of the $\mathrm{I} V$ curve $\left(\Delta \mathrm{V}_{\mathrm{m}} \pm 10 \mathrm{mV}\right.$, Fig. 4B) was decreased from $570 \mathrm{k} \Omega$ in the control to $341 \mathrm{k} \Omega$ in the presence of $\mathrm{DF}_{2}$. Similar results were obtained in another 17 preparations. Figure $4 \mathrm{C}$ summarizes the data. The average reduction of $\mathrm{R}_{\mathrm{i}}$ by the peptide was $17 \pm 3 \%(P \leq 0.001, n=18)$.

\section{Potentiation of potassium contractures by $\mathrm{DF}_{2}$}

Application of saline solutions with elevated $\mathrm{K}^{+}$in concentrations between 20 and $60 \mathrm{~mm}$ elicited graded slow depolarizations between 10 and $35 \mathrm{mV}$ resulting in graded contractures of the muscle fibres (Fig. 5A). Membrane depolarization was linearly correlated with the $\mathrm{K}^{+}$concentration in the bath. Generally, peak tension amplitude evoked by a given $\mathrm{K}^{+}$concentration varied among preparations (Fig. 5B). On average, it was $11 \pm 4 \mu \mathrm{N}$ at $20 \mathrm{mM}(n=9), 102 \pm 31 \mu \mathrm{N}$ at $30 \mathrm{mM}$ $(n=17), 273 \pm 93 \mu \mathrm{N}$ at $40 \mathrm{mM}(n=12)$ and $322 \pm 68 \mu \mathrm{N}$ at $60 \mathrm{mM}$ $\mathrm{K}^{+}(n=8)$.

In all $\mathrm{DF}_{2}$ experiments, $30 \mathrm{~mm} \mathrm{~K}^{+}$, which induced moderate contractures, was used to avoid fatigue of the muscle frequently observed during repeated $\mathrm{K}^{+}$application, particularly at higher concentrations. As shown for a representative experiment in Fig. $5 \mathrm{C} 100 \mathrm{nM} \mathrm{DF}_{2}$ increased the amplitude of the $\mathrm{K}^{+}$-induced contracture by $86 \%$ from $165 \mu \mathrm{N}$ in the control to $307 \mu \mathrm{N}$ with the peptide. The potentiating effect was reversed within $15 \mathrm{~min}$ by washing. Although present and reversible in successive peptide applications, the $\mathrm{DF}_{2}$ effect tended to decline during repeated measurements in a given experiment. Therefore, to obtain a dose response curve for the effect of $\mathrm{DF}_{2}$ on $\mathrm{K}^{+}$ 
contractures (Fig. 5D), each peptide concentration was applied only once to a given preparation. $\mathrm{DF}_{2}$ potentiation of tension development was dose-dependent. The threshold for a significant increase in contracture amplitude was between 0.1 and $1 \mathrm{nM}$, the $\mathrm{EC}_{50}$ value was at $40 \mathrm{nM}$, i.e. at similar concentrations as reported for neuromuscular effects by other FaRPs in crustaceans (Mercier et al., 1990; Skerrett et al., 1995; Worden et al., 1995; Jorge-Rivera \& Marder, 1996). Although peptide concentrations above $1 \mu \mathrm{M}$ were not tested, the data suggest that the maximally effective concentration is around $1 \mu \mathrm{M}$ with an average increase in the amplitude of $\mathrm{K}^{+}$evoked contractures by $122 \pm 28 \%(n=4)$.

\section{Effects of $\mathrm{DF}_{2}$ on contractions in current-clamped fibres}

As shown previously, in current- and voltage-clamp experiments graded contractions develop in these fibres only upon depolarization beyond the excitation-contraction (E-C) threshold. This potential coincides with the activation threshold of the high voltage-activated inward $\mathrm{Ca}^{2+}$ current at approximately $-40 \mathrm{mV}$. Tension development is positively correlated with this current (Weiss et al., 2001). In current-clamp experiments, application of $100 \mathrm{nM} \mathrm{DF}_{2}$ produced a strong increase in peak tension. For most fibres (nine of 13), electrical membrane responses remained graded upon addition of $\mathrm{DF}_{2}$. However, in four of the fibres that responded with graded electrical activity under control conditions (Fig. 6A), application of $\mathrm{DF}_{2}$ induced all-or-nothing action potentials (Fig. 6B). The plot of peak tension amplitude $\left(\mathrm{T}_{\text {peak }}\right)$ as a function of applied current quantitatively shows the potentiation of contraction by the peptide for a typical experiment (Fig. 6C). A plot of $\mathrm{T}_{\text {peak }}$ against membrane potential (Fig. 6D) shows that contractions develop only upon depolarizations beyond E-C threshold (approximately $-38 \mathrm{mV}$ ) in controls and in the presence of $\mathrm{DF}_{2}$. Regardless of the type of $\mathrm{DF}_{2}$ effects on electrical membrane responses, we never observed a significant change in E-C threshold with the peptide. In current- and voltage-clamped fibres, a sharp voltage threshold exists for the initiation of contractions (EC-threshold), which coincides with the voltage threshold for activation of the $\mathrm{I}_{\mathrm{Ca}}$. This is in contrast to the observation that depolarizations evoked by elevated $\mathrm{K}^{+}$elicit contractures already at membrane potentials more negative than the threshold found in voltage- and current-clamp experiments.

As was the case with peak tension amplitude under control conditions, the $\mathrm{DF}_{2}$-induced potentiation of contraction varied considerably among preparations (Fig. 7A) but was present in all experiments. Pooling of data shows a 26-fold increase in peak tension amplitude by the peptide used at a concentration of $100 \mathrm{nM}(P \leq 0.01, n=13$, Fig. 7B).

\section{$\mathrm{DF}_{2}$ effects on inward $\mathrm{Ca}^{2+}$ current in voltage-clamped fibres}

Isolated high-voltage-activated inward currents were measured under two-electrode voltage-clamp condition using the $\mathrm{K}^{+}$channel blocker TEA and 4-AP to suppress the outward current normally masking the inward current in Idotea extensor muscle fibres (Weiss et al., 2001). As previously shown on the single channel level (Erxleben \& Rathmayer, 1997), the inward current is carried by $\mathrm{Ca}^{2+}$ entry through dihydropyridine-sensitive L-type channels. As the density of $\mathrm{Ca}^{2+}$ currents varies greatly and larger currents can be recorded in Idotea muscle fibres with $\mathrm{Ba}^{2+}$ or $\mathrm{Sr}^{2+}$ as charge carrier (Weiss et al., 2001), $\mathrm{Ca}^{2+}$ was replaced by $\mathrm{Ba}^{2+}$. Application of $500 \mathrm{nM} \mathrm{DF}_{2}$ markedly enhanced the inward current (Fig. 8A). The peptide potentiated the peak and the integrated current over the range of stepping potentials investigated (Fig. 8B and C). Enhancement of the depolarization-activated inward currents was observed in two other fibres. On average, peak current was significantly potentiated by $\mathrm{DF}_{2}$ to $225 \pm 46 \%$, the integrated current to $244 \pm 43 \%$ of the controls ( $P \leq 0.03, n=3$, Fig. $8 \mathrm{D}$ and $\mathrm{E})$.
A
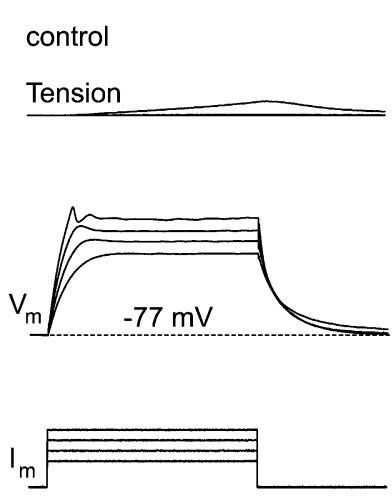

C

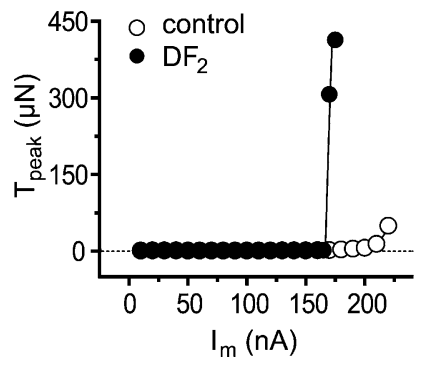

B
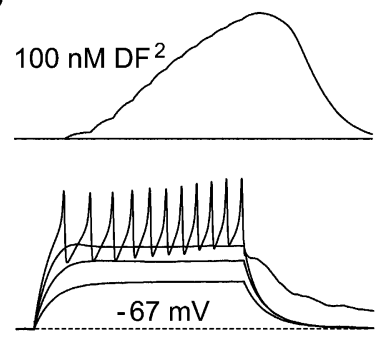

$175 \mu \mathrm{N}, 20 \mathrm{mV}, 200 \mathrm{nA}$ $100 \mathrm{~ms}$
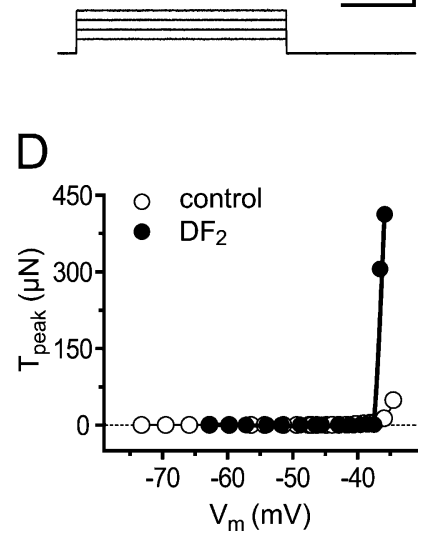

FIG. 6. $\mathrm{DF}_{2}$ increases muscle tension in current-clamped fibres. (A) Fibre with a membrane potential of $-77 \mathrm{mV}$, showing graded electrical responses upon depolarization beyond E-C threshold. Samples of four superimposed traces of tension, membrane potential $\left(V_{\mathrm{m}}\right)$, and applied current $\left(I_{\mathrm{m}}\right)$. Only the fourth current pulse elicited a small contraction. (B) Application of $100 \mathrm{nM} \mathrm{DF}_{2}$ depolarized the fibre from -77 to $-67 \mathrm{mV}$ and decreased $\mathrm{R}_{\mathrm{i}}$ from 327 to $266 \mathrm{k} \Omega$. The graded electrical membrane response was converted into all-ornothing action potentials accompanied by a large contraction. (C) Peak tension amplitude $\left(\mathrm{T}_{\text {peak }}\right)$ which occurs with a small delay after the end of the current pulses, is plotted as a function of applied current. (D) Peak tension amplitude $\left(\mathrm{T}_{\text {peak }}\right)$ related to membrane potential $\left(V_{\mathrm{m}}\right)$, which was determined at the end of the current pulses. E-C threshold of this fibre was at $-38 \mathrm{mV}$, and was not changed by the peptide.
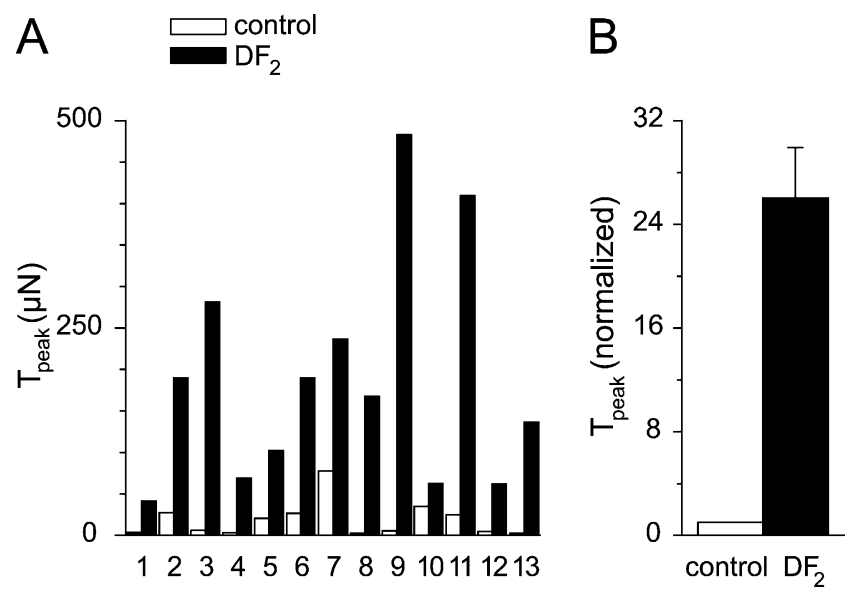

FIG. 7. Effects of $\mathrm{DF}_{2}$ on contractions of single current-clamped extensor muscle fibres. (A) Variability of peak tension amplitudes $\left(\mathrm{T}_{\text {peak }}\right)$ obtained in 13 preparations under control conditions and in the presence of $100 \mathrm{nM} \mathrm{DF}_{2}$. (B) Normalized data of the experiments shown in A indicating a 26-fold increase of $\mathrm{T}_{\text {peak }}$ with the peptide. 

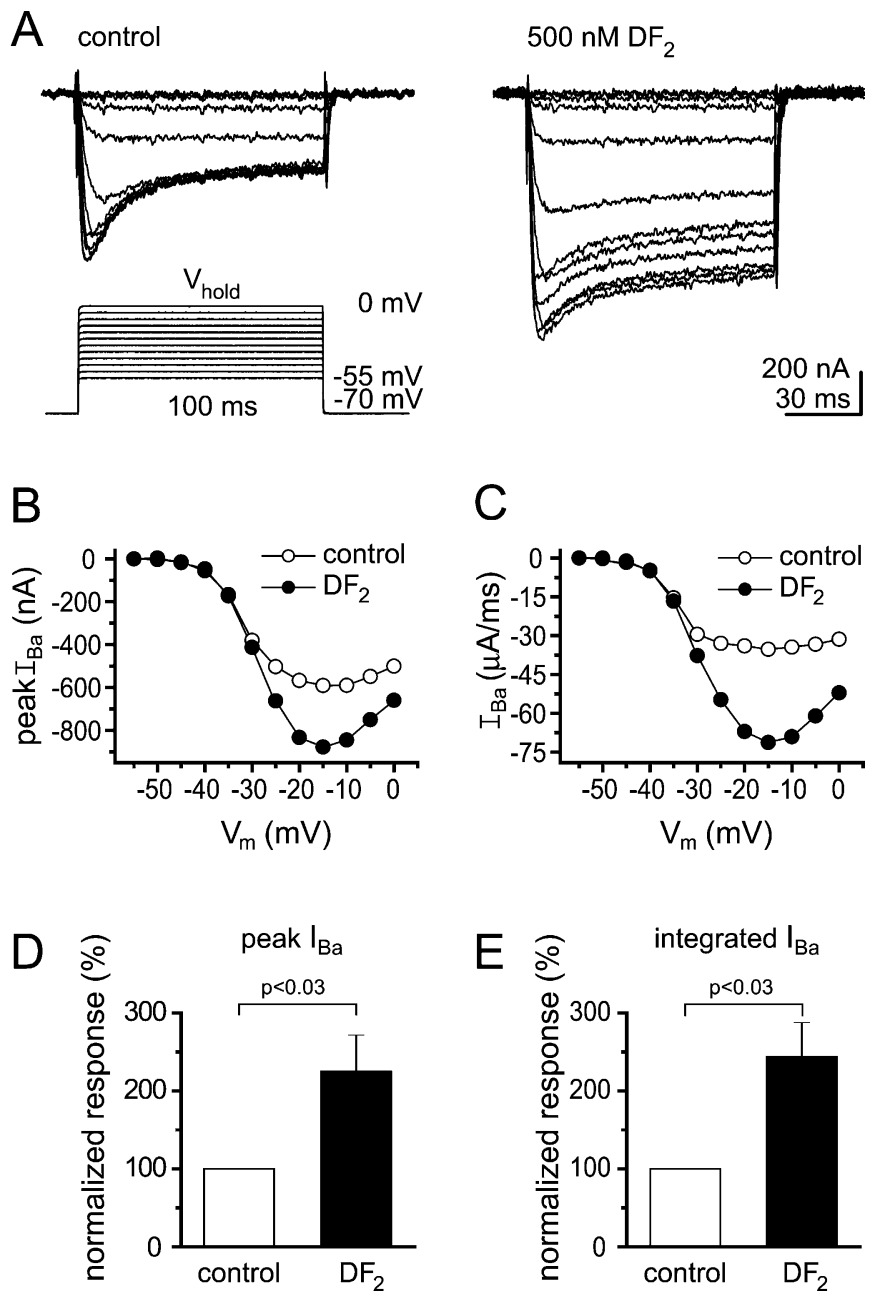

FIG. 8. $\mathrm{DF}_{2}$ enhances a depolarization-activated inward current in voltageclamped fibres. (A) Isolated inward currents in $10 \mathrm{mM} \mathrm{Ba}^{2+}\left(I_{\mathrm{Ba}}\right)$ elicited by a series of voltage steps increased by $5 \mathrm{mV}$ (inset left) from $-70 \mathrm{mV}$ holding potential to $0 \mathrm{mV}$, before (left traces) and $5 \mathrm{~min}$ after (right traces) application of $500 \mathrm{nM} \mathrm{DF}_{2}$. (B) Peak $I_{\mathrm{Ba}}$ from the experiment shown in A before and after application of the peptide plotted as a function of membrane potential. (C) Integrated $I_{\mathrm{Ba}}$ from the experiment shown in A before and after application of the peptide plotted as a function of membrane potential. (D and E) Bar graphs summarizing the results from three corresponding experiments for the effect of $\mathrm{DF}_{2}$ on peak (D) and integrated (E) $\mathrm{Ba}^{2+}$ inward current with the currents in controls normalized.

\section{Discussion}

\section{Localization of FaRPs in efferent neurons}

In this study, immunoreactivity was detected using a polyclonal antiserum raised against the synthetic tetrapeptide FMRFamide. As no FaRPs have been sequenced in isopods so far, the peptide(s) stained in Idotea are considered to belong to the group sharing the C-terminal sequence XLRFamide (with X standing for F or R), which includes $\mathrm{DF}_{2}$ and is widespread among crustaceans (Trimmer et al., 1987; Krajniak, 1991; Mercier et al., 1993; Weimann et al., 1993; Sithigorngul et al., 1998, 2001, 2002).

FMRFa immunoreactivity was found in various interneurons, but most prominently in a single pair of efferent neurons in pereion ganglion 5. With their specific size and topography, the two FMRFair neurons match homologous pairs of efferent neurons present in all pereion ganglia. They have been shown to be proctolin-immunoreactive in peg 4 , and allatostatin-immunoreactive in all other pereion ganglia. The present findings suggest colocalization of a FMRFamide and allatostatin in the pair of neurons in peg 5. This assumption is supported by ongoing studies employing antibodies marked with immunogold against allatostatin and FMRFamide (S. Kreissl, Utz \& W. Rathmayer, unpublished results). Proctolin exerts excitatory modulation, whereas allatostatin is an inhibitory modulator of neuromuscular parameters (Kreissl et al., 1999; Brüstle et al., 2001; Rathmayer et al., 2002b). The functional implications of colocalization of two peptides, which exert antagonistic modulation of the same pre- and post-synaptic neuromuscular parameters by converging actions on the same targets deserves further study.

The FMRFa-ir axons of the two neurons in peg 5 project ipsilaterally through nerves N3 into the ventral sinus nerve and the dorsal lateral nerve (DLN) running on both sides of the animal from head to telson. The axon in the sinus nerve forms numerous varicose endings closely attached to flexor muscle fibres of all segments, that in the DLN forms varicosities on parts of the two-segmental extensor muscle fibres of posterior segments only and in the pericardial organ. FMRFa immunoreactivity is absent on the one-segmental fibres of the extensor muscle. This situation resembles that in various leg muscles of the cockroach, where FMRFa-ir axons contact only some of the muscle fibres (Elia \& Orchard, 1995). Without electron microscopical studies one must be cautious in interpreting the varicosities in the DLN as neuromuscular synapses, which deliver the modulatory peptides directly onto the target where the nerve is in contact with muscle fibres. However, muscle fibres can be supplied with modulators from sources other than neuromuscular synapses. According to Delaleu (1970), the DLN in oniscoidean crustaceans is formed by axons coming from the segmental nerves $\mathrm{N} 3$ in all postantennal segments. It forms anteriorly the lateral cephalic plexus, and posteriorly the pericardial organ. Both structures function as neurohaemal organs (Chaigneau, 1983). In Idotea, each DLN and the pericardial organs contain FMRFa-ir, allatostatin-ir and proctolin-ir axons coming from homologous pairs of efferent neurons. In addition to the more direct supply by the varicosities on the muscle, the modulators are most likely released from the pericardial organs into the haemolymph and distributed to all extensor muscle fibres and other target muscles.

\section{Targets of the modulation and potentiation of contractions by FaRPs}

Potentiation of neuronally evoked muscle contractions by FaRPs including $\mathrm{DF}_{2}$ has been described in crab, lobster and crayfish. The peptides act mainly presynaptically by increasing transmitter release at neuromuscular junctions (Mercier et al., 1990; Pasztor \& Golas, 1993; Skerrett et al., 1995; Worden et al., 1995; Jorge-Rivera \& Marder, 1996; Friedrich et al., 1998). The increase of EPSC amplitude observed in the present study is most likely due to the same presynaptic effects, i.e. an increase in the number of transmitter quanta released by the action potentials invading the neuromuscular terminals. It was shown recently that the presynaptic enhancement of transmitter output by $\mathrm{DF}_{2}$ at crab neuromuscular junctions is caused by the modulation of $\omega$ conotoxin-sensitive $\mathrm{Ca}^{2+}$ channels which pharmacologically resemble vertebrate $\mathrm{N}$-type channels, but not of $\omega$-agatoxin-sensitive channels which resemble vertebrate P/Q-type $\mathrm{Ca}^{2+}$ channels (Rathmayer et al., 2002a). As the endings of the slow excitatory axon lack N-type $\mathrm{Ca}^{2+}$ channels, modulation by $\mathrm{DF}_{2}$ is restricted to the junctions of the fast axon that is endowed with P/Q- and N-type channels. However, in neurons of Aplysia and of the pond snail Helisoma, FaRPs cause a presynaptic inhibition of transmitter release by reducing both $\mathrm{Ca}^{2+}$ influx into the terminals and the effectiveness of $\mathrm{Ca}^{2+}$ on the secretory machinery (Man-Son-Hing et al., 1989; Haydon et al., 1991; Cropper et al., 1994). In some molluscan neurons, FMRFamide exerts two 
effects by activating different currents. One effect is a slow response caused by activating nonvoltage-dependent $\mathrm{K}^{+}$and partially suppressing $\mathrm{Ca}^{2+}$ conductance, both of which involve G-protein-coupled signalling (Cottrell et al., 1984; Brezina et al., 1987a,b; Green et al., 1994; Lesser et al., 1997). Another effect of FMRFamide is the direct gating of an amiloride-sensitive channel with a high selectivity for $\mathrm{Na}^{+}$over $\mathrm{K}^{+}$and divalent ions without involvement of $\mathrm{G}$ proteins, which results in a rapid depolarization (Ruben et al., 1986; Green et al., 1994; Cottrell, 1997).

In Idotea, the presynaptic effect of $\mathrm{DF}_{2}$ on transmitter release was always accompanied by postsynaptic effects at the muscle membrane. The observed depolarization of the extensor muscle fibres by the peptide is in accord with findings in shrimp stomach muscle (Meyrand \& Marder, 1991) but is in contrast to our observations in the closer muscle of the crab Eriphia, as well as of other crustaceans where three FaRPs including $\mathrm{DF}_{2}$ did not change membrane potential or input resistance of muscle fibres (Mercier et al., 1990; Skerrett et al., 1995; Worden et al., 1995; Jorge-Rivera \& Marder, 1996). The fact that FaRPs exert different, sometimes opposing effects in different species, is further substantiated by findings that other FaRPs than those just mentioned even cause a slight increase in input resistance in muscles, e.g. of lobster, shrimp and crayfish (Mercier et al., 1990; Meyrand \& Marder, 1991; Skerrett et al., 1995).

Also in muscles of noncrustaceans, the effects of different FaRPs vary and show opposite effects. YGGFMRFamide reduces resting $\mathrm{K}^{+}$ conductance of extensor tibiae muscle fibres of the locust (Walther et al., 1998). However, in another muscle of the same species, the insect FaRP SchistoFLRFamide, ManducaFLRFamide and leucomyosuppressin induce hyperpolarization (Lange \& Cheung, 1999). FMRFamide-activated $\mathrm{K}^{+}$currents have been found in radula muscles of Aplysia (Cropper et al., 1994; Scott et al., 1997). In heart muscle cells of the snail Lymnaea, FMRFamide activates a cobalt-sensitive cation-conducting channel that normally carries $\mathrm{Ca}^{2+}$ but in the absence of $\mathrm{Ca}^{2+}$ admits $\mathrm{Na}^{+}$and also $\mathrm{Ba}^{2+}$, even at the cells resting potential (Brezden et al., 1991). Variability of the neuromuscular effects of different FaRPs in the same species, but also of identical peptides in different species have been observed frequently and may reflect differences among the receptors and targets of intracellular signalling pathways. In Idotea, the depolarization of muscle fibres and the decrease of membrane resistance were blocked when $\mathrm{Co}^{2+}$ substituted $\mathrm{Ca}^{2+}$ but were insensitive to amiloride and nifedipine. These effects are thus unlikely due to the directly peptide-gated $\mathrm{Na}^{+}$current known from snail neurons but suggest the participation of nifedipineinsensitive nonL-type $\mathrm{Ca}^{2+}$ currents. It has to remain open at present whether the current responsible for the depolarization is carried exclusively by $\mathrm{Ca}^{2+}$ or whether $\mathrm{Ca}^{2+}$ just sensitizes another inward current. This has been shown to be the case in the depolarization exerted by the peptides proctolin and a FMRFamide in crustacean stomatogastric neurons (Golowasch \& Marder, 1992; Swensen \& Marder, 2000). In these preparations, however, the effect of $\mathrm{Ca}^{2+}$ is opposite to that observed in Idotea muscles because substituting $\mathrm{Ca}^{2+}$ with $\mathrm{Co}^{2+}$ increased the inward current. If a $\mathrm{Ca}^{2+}$ current, activated by $\mathrm{DF}_{2}$, plays a sensitizing role for additional inward currents, this would explain why we never observed contractions accompanying the depolarizations. The $\mathrm{Ca}^{2+}$ entry could just be too small for triggering the $\mathrm{Ca}^{2+}$-induced $\mathrm{Ca}^{2+}$ release from the sarcoplasmatic reticulum, which is essential for tension generation in these fibres (Weiss et al., 2001).

The potentiation of $\mathrm{K}^{+}$contractures in the absence of neuronal activity upon application of $\mathrm{DF}_{2}$ has been observed also in other crustacean preparations (Worden et al., 1995; Jorge-Rivera \& Marder, 1996). Whereas in voltage-clamped fibres, the E-C threshold is quite narrow at $-38 \pm 1 \mathrm{mV}$ and identical with the activation threshold for the high voltage-activated inward $\mathrm{Ca}^{2+}$ current (Weiss et al., 2001), $\mathrm{K}^{+}$contractures already develop at much smaller depolarizations starting from membrane potentials of approximately $-60 \mathrm{mV}$. One possible explanation for this discrepancy is the presence of slowly activating, nonL-type $\mathrm{Ca}^{2+}$ channels. Their modulation by $\mathrm{DF}_{2}$ could explain the potentiation of $\mathrm{K}^{+}$contractures at small depolarizations.

The described pre- and postsynaptic excitatory effects of $\mathrm{DF}_{2}$ and the presence of a pair of FMRFamide-immunoreactive efferent neurons suggest an involvement of a FMRFamide-related peptide in the modulation of muscle contraction in Idotea. In vivo, this peptide should increase the efficacy of motor input to muscles and result in the potentiation of muscle performance.

\section{Acknowledgements}

We thank S. Djokaj for the macropatch recordings, R. Eberle and B. Rapp for technical help, M. Thimm for maintaining the animals, and M. A. Cahill for help with the English. This investigation was supported by grants from the Deutsche Forschungsgemeinschaft to W.R. (Ra 113/8 1,8 3).

\section{Abbreviations}

$\mathrm{DF}_{2}$, Asp-Arg-Asn-Phe-Leu-Arg-Phe- $\mathrm{NH}_{2}$ or DRNFLRFamide; DLN, dorsal lateral nerve, E-C threshold, excitation-contraction threshold; EPSCs, excitatory postsynaptic currents; FaRPs, FMRFamide-related peptides; ir, immunoreactive, IR, immunoreactivity; peg, pereion ganglion; Pe, pereion segment; Pl, pleon segment.

\section{References}

Askwith, C.C., Cheng, C., Ikuma, M., Benson, C., Price, M.P. \& Welsh, M.J. (2000) Neuropeptide FF and FMRFamide potentiate acid-evoked currents from sensory neurons and proton-gated DEG/ENaC channels. Neuron, 26, 133141.

Brezden, B.L., Benjamin, P.R. \& Gardner, D.R. (1991) The peptide FMRFamide activates a divalent cation-conducting channel in heart muscle cells of the snail Lymnaea stagnalis. J. Physiol. (Lond.), 443, 727738.

Brezina, V., Eckert, R. \& Erxleben, C. (1987a) Modulation of potassium conductances by an endogenous neuropeptide in neurons of Aplysia cali fornica. J. Physiol. (Lond.), 382, 267290.

Brezina, V., Eckert, R. \& Erxleben, C. (1987b) Suppression of calcium current by an endogenous neuropeptide in neurones of Aplysia californica. J. Physiol. (Lond.), 388, 565595.

Brüstle, B., Kreissl, S., Mykles, D.L. \& Rathmayer, W. (2001) The neuropeptide proctolin induces phosphorylation of a $30 \mathrm{kDa}$ protein associated with the thin filament in crustacean muscle. J. Exp. Biol., 204, 26272635.

Chaigneau, J. (1983) Neurohemal organs in Crustacea. In Gupta, A.P. (ed), Neurohemal Organs of Arthropods. Their Development, Evolution, Struc tures, and Functions. Thomas, Springfield, pp. 5389.

Cottrell, G.A. (1997) The first peptide-gated ion channel. J. Exp. Biol., 200, 23772386.

Cottrell, G.A., Davies, N.W. \& Green, K.A. (1984) Multiple actions of a molluscan cardioexcitatory neuropeptide and related peptides on identified Helix neurons. J. Physiol. (Lond.), 356, 315333.

Cropper, E.C., Brezina, V., Vilim, F.S., Harish, O., Price, D.A., Rosen, S., Kupfermann, I. \& Weiss, K.R. (1994) FRF peptides in the ARC neuromuscular system of Aplysia: Purification and physiological actions. J. Neuro physiol., 72, 21812195.

Delaleu, J. (1970) Le systeme nerveux intrapericardique et ses relations avec le systeme nerveux central chez trois Oniscoides: Porcellio dilatatus (B.), Helleria brevicornis (E.) et Ligia oceanica (L.). Bull. Soc. Zool. France, 95, 201210.

Demassieux, C. (1979) Le système neurosécréteur du crustacé isopode Asellus aquaticus (Linné). Crustaceana, 37, 7179.

Elia, A.J. \& Orchard, I. (1995) Peptidergic innervation of leg muscles of the cockroach, Periplaneta americana (L.), and a possible role in modulation of muscle contraction. J. Comp. Physiol., 176, 425435.

Erxleben, C. \& Rathmayer, W. (1997) A dihydropyridine-sensitive voltagedependent calcium channel in the sarcolemmal membrane of crustacean muscle. J. General Physiol., 109, 313326. 
Friedrich, R.W., Molnar, G.F., Schiebe, M. \& Mercier, A.J. (1998) Protein kinase $\mathrm{C}$ is required for long-lasting synaptic enhancement by the neuropeptide DRNFLRFamide in crayfish. J. Neurophysiol., 79, 11271131.

Golowasch, J. \& Marder, E. (1992) Proctolin activates an inward current whose voltage dependence is modified by extracellular $\mathrm{Ca}^{2+}$. J. Neurosci., 12, 810817.

Green, K.A., Falconer, S.W. \& Cottrell, G.A. (1994) The neuropeptide PheMet-Arg-Phe- $\mathrm{NH}_{2}$ (FMRFamide) directly gates two ion channels in an identified Helix neurone. Pflügers Arch., 428, 232240.

Greenberg, M.J. \& Price, D.A. (1992) Relationships among the FMRFamidelike peptides. Prog. Brain Res., 92, 2537.

Haydon, P.G., Man-Son-Hing, H., Doyle, R.T. \& Zoran, M. (1991) FMRFamide modulation of secretory machinery underlying presynaptic inhibition of synaptic transmission requires a pertussis toxin-sensitive G-protein. J. Neu rosci., 11, 38513860 .

Jorge-Rivera, J.C. \& Marder, E. (1996) TNRNFLRFamide and SDRNFLRFamide modulate muscles of the stomatogastric system of the crab Cancer borealis. J. Comp. Physiol. 179, 741751.

Jorge-Rivera, J.C., Sen, K., Birmingham, J.T., Abbott, L.F. \& Marder, E. (1998) Temporal dynamics of convergent modulation at a crustacean neuromuscular junction. J. Neurophysiol., 80, 25592570.

Krajniak, K.G. (1991) The identification and structure-activity relations of a cardioactive FMRFamide-related peptide from the Blue crab, Callinectes sapidus. Peptides, 12, 12951302

Kravitz, E.A., Glusman, S., Harris-Warrick, R.M., Livingston, M.S., Schwarz, T. \& Goy, M.F. (1980) Amines and peptides as neurohormones in lobsters: actions on neuromuscular preparations and preliminary behavioural studies. J. Exp. Biol., 89, 159175.

Kreissl, S., Weiss, T., Djokaj, S., Balezina, O. \& Rathmayer, W. (1999) Allatostatin modulates skeletal muscle performance in crustaceans through pre- and postsynaptic effects. Eur. J. Neurosci., 11, 25192530.

Lange, A.B. \& Cheung, I.L. (1999) The modulation of skeletal muscle contraction by FMRFamide-related peptides of the locust. Peptides, 20, 14111418

Lesser, W., Falconer, S.W. \& Cottrell, G.A. (1997) Actions of FMRFamiderelated peptides on the $\mathrm{gCa}^{2+}$ of the $\mathrm{C} 1$ neuron in Helix aspersa. Peptides, $\mathbf{1 8}$, 909911.

Man-Son-Hing, H., Zoran, M.J., Lukowiak, K. \& Haydon, P.G. (1989) A neuromodulator of synaptic transmission acts on the secretory apparatus as well as on ion channels. Nature, 341, 237239.

Marder, E., Calabrese, R.L., Nusbaum, M.P. \& Trimmer, B.A. (1987) Distribution and partial characterization of FMRFamide-like peptides in the stomatogastric nervous system of the rock crab, Cancer borealis, and the spiny lobster, Panulirus interruptus. J. Comp. Neurol., 259, 150163.

Mercier, A.J., Badhwar, A., Weston, A.D. \& Klose, M. (2002) Intracellular signals that mediate synaptic modulation by a FMRFamide-like neuropeptide in crayfish. In Wiese, K., (Ed.) The Crustacean Nervous System. Springer, Heidelberg, pp. 4962.

Mercier, A.J., Orchard, I., TeBrugge, V. \& Skerrett, M. (1993) Isolation of two FMRFamide-related peptides from crayfish pericardial organs. Peptides, 14, 137143.

Mercier, A.J., Schiebe, M. \& Atwood, H.L. (1990) Pericardial peptides enhance synaptic transmission and tension in phasic extensor muscles of crayfish. Neurosci. Lett., 111, 9298.

Meyrand, P. \& Marder, E. (1991) Matching neural and muscle oscillators: control by FMRFamide-like peptides. J. Neurosci., 11, 11501161.

Oelschläger, H.A., Helpert, C. \& Northcutt, R.G. (1998) Coexistence of FMRFamide-like and LHRF-like immunoreactivity in the terminal nerve and forebrain of the big brown bat, Eptesicus fuscus. Brain Behav. Evol., 52, 139147.

Orchard, I., Lange, A.B. \& Bendena, W.G. (2001) FMRFamide-related peptides: a multifactoral family of structurally related neuropeptides in insects. Adv. Insect Physiol., 28, 267329.
Pasztor, V.M. \& Golas, L.B. (1993) The modulatory effects of serotonin, neuropeptide F1 and proctolin on the receptor muscles of the lobster abdominal stretch receptor and their exoskeletal muscle homologues. J. Exp. Biol., 174, 363374.

Price, D.A. \& Greenberg, M.J. (1977) Purification and characterization of a cardioexcitatory neuropeptide from the central ganglia of a bivalve mollusc. Prep. Biochem., 7, 261281.

Rathmayer, W., Djokaj, S., Gaydukov, A. \& Kreissl, S. (2002a) The neuromuscular junctions of the slow and the fast excitatory axon in the closer of the crab Eriphia spinifrons are endowed with different $\mathrm{Ca}^{2+}$ channel types and allow neuron-specific modulation of transmitter release by two neuropeptides. J. Neurosci., 22, 708717.

Rathmayer, W. \& Erxleben, C. (1983) Identified muscle fibers in a crab. I. Characteristics of excitatory and inhibitory neuromuscular transmission. J. Comp. Physiol., 152, 411420.

Rathmayer, W., Erxleben, C., Djokaj, S., Gaydukov, A., Kreiss1, S. \& Weiss, T. (2002b) Antagonistic modulation of neuromuscular parameters in crustaceans by the peptides proctolin and allatostatin, contained in identified motor neurons. In Wiese, K., (Ed.) The Crustacean Nervous System. Springer, Heidelberg, pp. 219.

Ruben, P., Johnson, J.W. \& Thompson, S. (1986) Analysis of FMRF-amide effects on Aplysia bursting neurons. J. Neurosci., 6, 252259.

Scott, M.L., Brezina, V. \& Weiss, K.R. (1997) Ion currents and mechanisms of modulation in the radula opener muscle of Aplysia. J. Neurophysiol., 78, 23722387.

Sithigorngul, P., Pupuem, J., Krungkasem, C., Longyant, S., Chaivisuthangkura, P., Sithigorngul, W. \& Petsom, A. (2002) Seven novel FMRFamide-like neuropeptide sequences from the eyestalk of the giant tiger prawn Penaeus monodon. Comp. Biochem. Physiol., 131, 325337.

Sithigorngul, P., Saraithongkum, W., Jaideechoey, S., Longyant, S. \& Sithigorngul, W. (1998) Novel FMRFamide-like neuropeptides from the eyestalk of the giant freshwater prawn Macrobrachium rosenbergii. Comp. Biochem. Physiol., 120, 587595.

Sithigorngul, P., Saraithongkum, W., Longyant, S., Panchan, N., Sithigorngul, W. \& Petsom, A. (2001) Three more novel FMRFamide-like neuropeptide sequences from the eyestalk of the giant freshwater prawn Macrobrachium rosenbergii. Peptides, 22, 191197.

Skerrett, M., Peaire, A., Quigley, P. \& Mercier, A.J. (1995) Physiological effects of two FMRFamide-related peptides from the crayfish Procambarus clarkii. J. Exp. Biol., 198, 109116.

Swensen, A.M. \& Marder, E. (2000) Multiple peptides converge to activate the same voltage-dependent current in a central pattern-generating circuit. J. Neurosci., 15, 67526759 .

Tierney, A.J., Blanck, J. \& Mercier, A.J. (1997) FMRFamide-like peptides in the crayfish (Procambarus clarkii) stomatogastric nervous system: distribution and effects on the pyloric motor pattern. J. Exp. Biol., 200, 32213233.

Trimmer, B.A., Kobierski, L.A. \& Kravitz, E.A. (1987) Purification and characterization of FMRFamide-like immunoreactive substances from the lobster nervous system: isolation and sequence analysis of two closely related peptides. J. Comp. Neurol., 266, 1626.

Walther, C., Zittlau, K.E., Murck, H. \& Voigt, K. (1998) Resting membrane properties of locust muscle and their modulation I. Actions of the neuropeptides YGGFMRFamide and proctolin. J. Neurophysiol., 80, 771784.

Weimann, J.M., Marder, E., Evans, B. \& Calabrese, R.L. (1993) The effects of SDRNFLRFamide and TNRNFLRFamide on the motor patterns of the stomatogastric ganglion of the crab Cancer borealis. J. Exp. Biol., 181, 126.

Weiss, T., Erxleben, C. \& Rathmayer, W. (2001) Voltage-clamp analysis of membrane currents and excitation-contraction coupling in a crustacean muscle. J. Muscle Res. Cell Motil., 22, 329344.

Worden, M.K., Kravitz, E.A. \& Goy, M.F. (1995) Peptide $F_{1}$, an N-terminally extended analog of FMRFamide, enhances contractile activity in multiple target tissues in lobster. J. Exp. Biol., 198, 97108. 